\title{
Effect of Chicken Type and Reactor Temperature on Biofuel Yields from Pyrolysis of Poultry Litter
}

\author{
Pious O. Okekunle (D. Eng.), \\ Olukunle E. Itabiyi (Ph.D), \\ Emmanuel O. Olafimihan (Ph.D), \\ Ibraheem O. Alayande (B. Tech), \\ Mutiu O. Najeemdeen (B. Tech), \\ Omotolani A. Adisa (B. Tech), \\ Adedapo B. Popoola (B. Tech), \\ Department of Mechanical Engineering, Ladoke Akintola University of \\ Technology, Ogbomoso, Oyo state, Nigeria
}

Doi: 10.19044/esj.2019.v15n3p61 ～URL:http://dx.doi.org/10.19044/esj.2019.v15n3p61

\begin{abstract}
Efficient management of poultry litter resulting from the ever growing agricultural industry is key to saving the global environment. In this study, effect of chicken type and reactor temperature on biofuel yields from pyrolysis of poultry litter has been studied. Samples of fresh droppings of broiler and layer chickens were collected from the poultry farm of Ladoke Akintola University of Technology, Ogbomoso, South-Western Nigeria. The samples were sun dried for two days and afterwards oven-dried at a temperature of 105 ${ }^{\circ} \mathrm{C}$ for 10 minutes. Samples of $40 \mathrm{~g}$ each were pyrolyzed at four different reactor temperatures $\left(300,400,500\right.$ and $\left.600{ }^{\circ} \mathrm{C}\right)$ for 15 minutes. The yield of pyro-oil and pyro-gas from the litter of the two chicken types increased with reactor temperature while char yield decreased with it. Pyro-oil yield from broiler litter was higher than that from layer litter at all temperatures while pyro-gas yield from layer litter was higher than that from broiler litter at all the conditions studied. The highest yield of pyro-oil $\left(65.10 \%\right.$ at $\left.600{ }^{\circ} \mathrm{C}\right)$ was obtained from broiler litter while the highest yields of char $\left(42.12 \%\right.$ at $\left.300{ }^{\circ} \mathrm{C}\right)$ and pyro-gas $\left(25.7 \%\right.$ at $\left.600{ }^{\circ} \mathrm{C}\right)$ were recorded for layer litter. The presence of alkali metals in different proportions in broiler and layer litter was identified to have influenced pyrolysis secondary reactions. Cellulose, hemicellulose and lignin may also be in different percentages in the two types of chicken litter.
\end{abstract}

Keywords: Poultry litter, pyrolysis, biofuels, global environment 


\section{Introduction}

Depletion of fossil fuel resources, emission of greenhouse gases and ever increasing energy demand have brought about global concerns regarding the use of fossil fuels (Hirosaka et al., 2008). Energy experts are worried about energy supply for sustainable development. Sequel to these, alternatives to conventional fuels are being sought (Abdulrahman et al., 2016). Biomass has continued to attract interest as a viable alternative (Jahirul et al., 2012). Energy crops, agricultural residues, solid and municipal wastes have been identified as potential biomass feedstock for biofuels production through biochemical and thermochemical processes (Parveen et al., 2011). Thermochemical processes are used quite often because they are capable of giving solid, liquid and gaseous biofuels simultaneously (Di Blasi et al., 1999; ,Babu and Chaurasia, 2004).

In Nigeria, agricultural industry, especially poultry farming, is fast growing (Adeoye et al., 2015; Olumayowa and Abiodun, 2011). With this growth comes the challenge of disposing a large volume of poultry litter being generated. It has been reported that Nigeria generated 932.5 metric tons of poultry litter in 2012 (Adewumi et al., 2011). Common methods for poultry litter disposal include direct burning, burying, dumping in remote areas or being used as organic manure, and anaerobic generation of biogas (Kim et al., 2009). Many of these conventional disposal methods cause environmental and water pollution. Hence the need to devise other methods of disposing poultry litter while at the same time generate value added products and biofuels (Ezeonu et al., 2014).

Although many researchers have used pyrolysis (one of the thermochemical processes) to convert a number of biomass feedstock into biofuels (Scotts et al., 1988; Piskorz et al., 1998; Horne and Williams, 1996; Antal, 1983; Scotts and Piskorz, 1982; Di Blasi et al., 2001; Di Blasi and Branca, 2001; Lu et al., 2010; Okekunle et al., 2011; Okekunle et al., 2015, Okekunle et al., 2016), poultry manure is rarely used. Some researchers have worked on pyrolytic conversion of poultry litter (Baniasadi et al., 2016; Mante and Agblevor, 2010). In all of these, the effect of chicken type on biofuels yield spectra from pyrolysis of poultry litter has not been investigated. Therefore, in this work, the effect of chicken type and temperature on biofuels yield spectra from poultry litter pyrolysis is being investigated.

\section{Materials and Methods}

\subsection{Sample procurement and processing}

Fresh droppings of broiler and layer chickens were collected from the poultry farm of Ladoke Akintola University of Technology, Ogbomoso, South-Western Nigeria. Fresh droppings were procured to avoid contamination with other materials. The samples were sun dried for two days 
and then subsequently oven-dried at a temperature of $105^{\circ} \mathrm{C}$ for 10 minutes in Food Science and Engineering Laboratory of Ladoke Akintola University of Technology, Nigeria.

\subsection{Experimental setup}

Figure 1 shows the exploded view of the fixed bed reactor used for the pyrolysis process. The reactor comprises of a cylindrical retort with a bottle neck to enhance a firm closure of the lid, products collector pipe, tar collectors and a pyro-gas receiver. Carrier gas (nitrogen) was used to purge the reactor and sweep the volatiles from the reactor. The collector pipe channeled the volatiles stream into the tar collectors which were immersed in an ice- bath (tar trapper) for condensation of condensable gases and non-condensable gases passed on to the gas collector. Staged tar trappers were employed to ensure that all tarry compounds were condensed in the tar collectors.

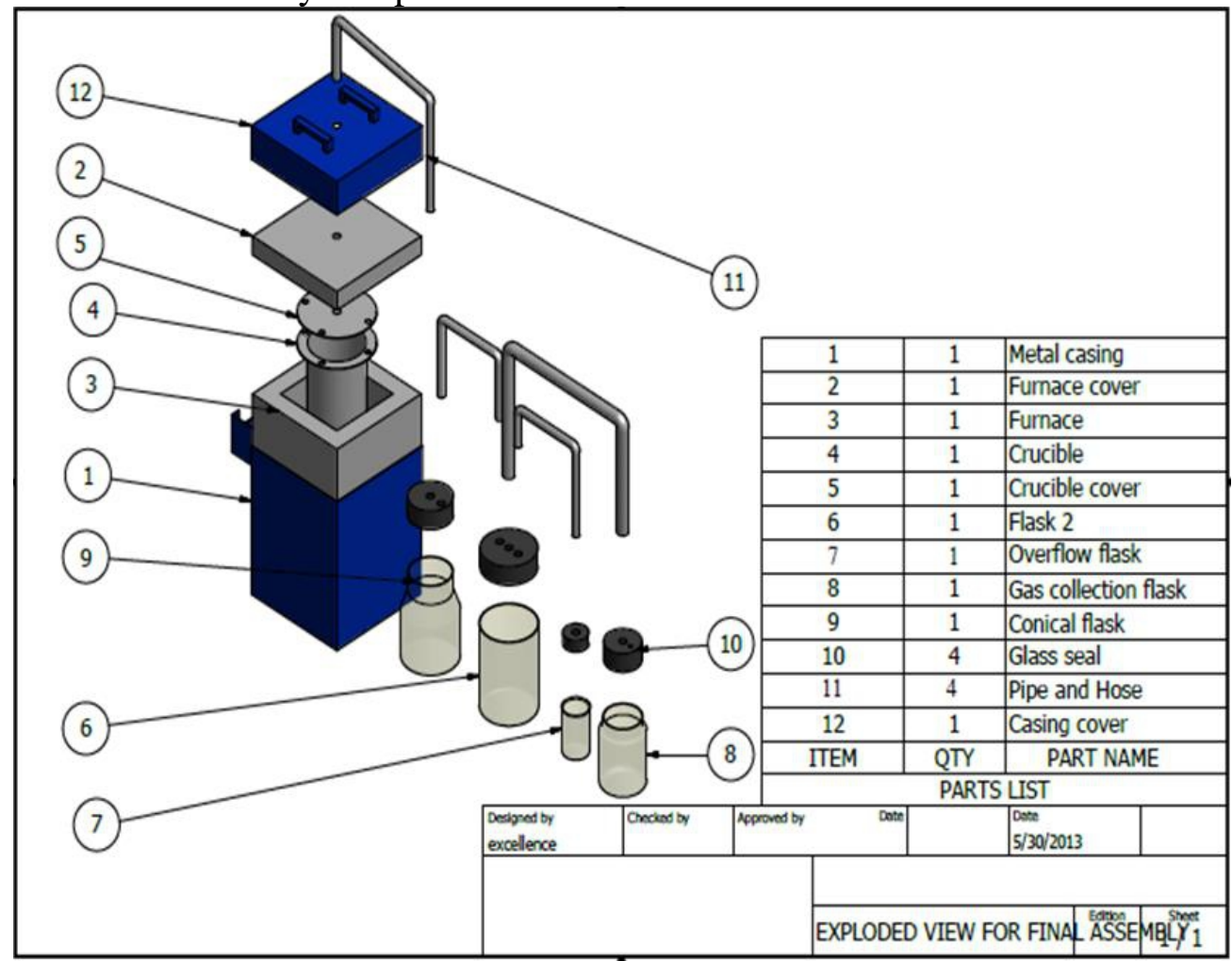

Figure 1: Exploded view of the pyrolysis unit

In each experimental run, $40 \mathrm{~g}$ of each sample of broiler and layer litter was introduced into the crucible, fastened with bolts and nuts, inserted into the furnace and covered. The weighed samples were pyrolysed at varying temperatures of $300,400,500$ and $600{ }^{\circ} \mathrm{C}$ for 15 minutes. The yield of char 
and tar (pyro-oil) were obtained and expressed as percentage of the initial weight of the sample. The yield of gas was obtained by conservation of mass.

\section{Results and Discussion}

\subsection{Char yield}

Figure 2 shows the yield of char from pyrolysis of broiler and layer litter at different temperatures. From the figure, it can be seen that layer litter char yield at $300{ }^{\circ} \mathrm{C}$ was higher than that of broiler litter. As the process temperature increased however, up to $500{ }^{\circ} \mathrm{C}$, char yield from both chicken types were within the same range, with broiler litter char yield having higher values. At $600{ }^{\circ} \mathrm{C}$, the difference between char yields from the litter of both chicken types was insignificant. This trend in char yield may be due to different proportions of alkali metals and lignin in their droppings. Alkali metals are reported to catalyze char formation (DeGroot and Shafizadeh, 1984) and lignin has been identified as the main source of char formation (Yang et al., 2006). For both types of chicken litter, the yield of char decreased with increase in pyrolysis temperature. This is in agreement with the pyrolysis convention. Char yield ranges for broiler and layer litter were $20.95-30.82 \%$ and $21.62-42.12 \%$, respectively.

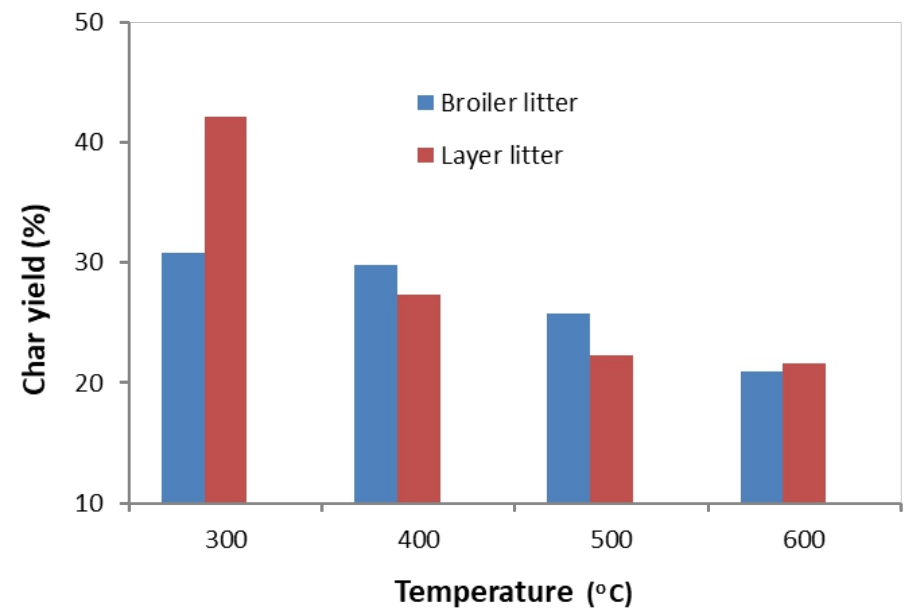

Figure 2: Char yield from broiler and layer litter at different temperatures

\subsection{Pyro-oil yield}

Figure 3 shows pyro-oil yield from broiler and layer litter at different temperatures. It can be seen that pyro-oil yields obtained at all temperatures from broiler litter were higher than those of layer litter. This suggests a higher presence of cellulose in broiler litter than layer litter. Cellulose has been identified as the main source of pyro-oil in biomass pyrolysis (Burhenne et al., 2013). Figure 3 also reveals that pyro-oil yield slightly increased with 
temperature, the phenomenon contrary to pyrolysis convention, especially above $500{ }^{\circ} \mathrm{C}$. This trend may also be connected to the presence of metals in chicken feeds, which, mostly likely, has altered the sequence of events during secondary reactions in favour of pyro-oil yield. Further studies will be needed to fully unravel this trend. Pyro-oil yield ranges for broiler and layer litter were $59.76-65.10 \%$ and $41.34-54.05 \%$, respectively.

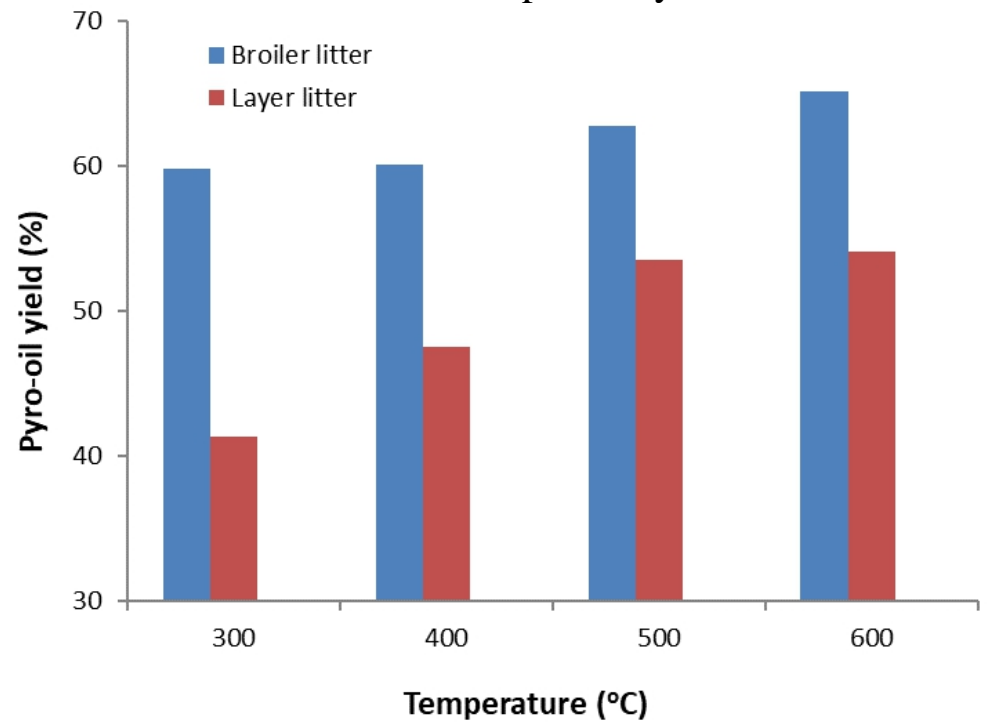

Figure 3: Pyro-oil yield from broiler and layer litter at different temperatures

\subsection{Pyro-gas yield}

Figure 4 shows the gas yield obtained at different pyrolysis temperatures for broiler and layer litter. From the figure, gas yields from layer litter at all temperatures were much higher than those from broiler litter. This suggests a higher percentage of hemicellulose in layer litter. Hemicellulose and cellulose have been linked with high yield of pyro-gas (Burhenne et al., 2013). Pyro-gas yield ranges for broiler and layer litter were $9.42-13.95 \%$ and $16.54-25.7 \%$, respectively. 


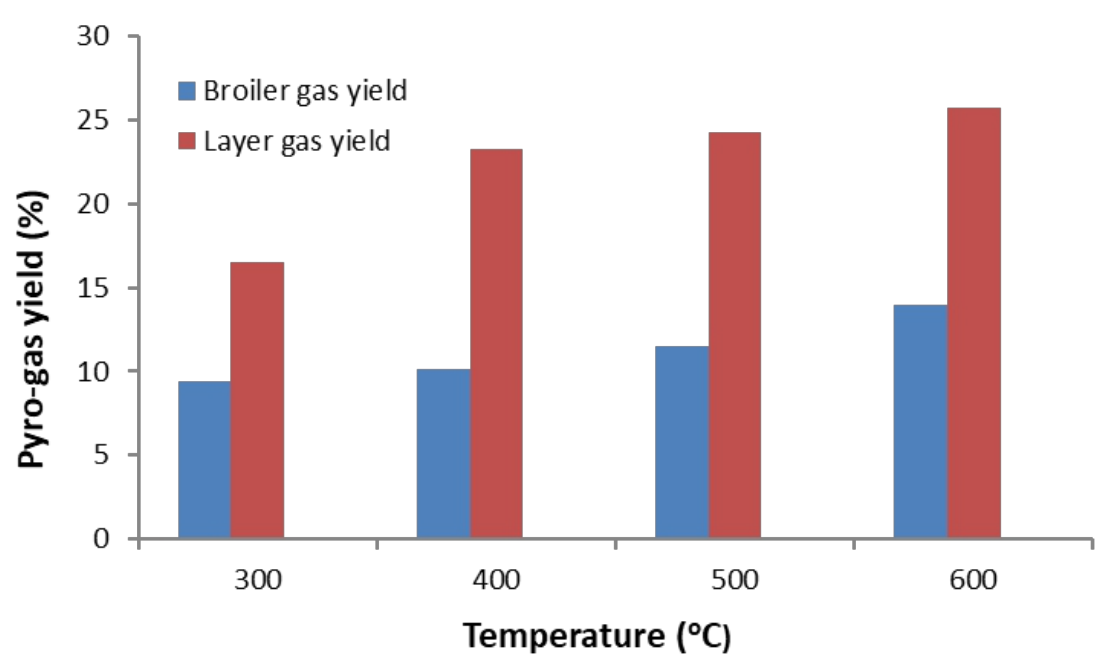

Figure 4: Pyro-gas yield from broiler and layer litter at different temperatures

\section{Conclusion}

Effect of chicken type and reactor temperature on the yield of biofuels from poultry litter pyrolysis in a fixed bed reactor has been studied. Findings revealed that broiler litter gave the highest yield of pyro-oil $(65.10 \%$ at 600 $\left.{ }^{\circ} \mathrm{C}\right)$ while layer litter gave the highest yields of char $\left(42.12 \%\right.$ at $\left.300{ }^{\circ} \mathrm{C}\right)$ and pyro-gas $\left(25.7 \%\right.$ at $\left.600{ }^{\circ} \mathrm{C}\right)$. The presence of alkali metals in poultry feed was identified to have interfered with pyrolysis secondary reactions. Results also suggest that the percentage compositions of cellulose, hemicellulose and lignin in broiler and layer droppings may not be the same.

\section{References:}

1. Abdulrahman, R.K., Zangana, M.H., Aziz, R.I., Karem, R.M., and Hussain, B.H. (2016). Biofuel from cow tallow: A case study. European Scientific Journal, 12(6), 299-306.

2. Adeoye, P.A., Man, H.C., Soom, M.A., Thamer A.M., and Oluwakunmi, A.C. (2015). Poultry waste generation, management and the environment: A case study of Minna, North Central Nigeria. Journal of Solid Waste Technology and Management, 41(2), 162-172.

3. Adewumi, A.A., Adewumi, I.K., and Olaleye, V.F. (2011). Livestock waste menace: Fish wealth-solution. African Journal of Environmental Science and Technology, 5, 149-154.

4. Antal, M.J. (1983). Effects of reactor severity on the gas-phase pyrolysis of cellulose and kraft lignin-derived volatile matter. Industrial Engineering Production Research and Development, 22, 366-375. 
5. Babu, B.V. and Chaurasia A.S. (2004). Heat transfer and kinetics in the pyrolysis of shrinking biomass particle. Chemical Engineering science, 59, 1999-2012.

6. Baniasadi, M., Tugnoli, A., Conti, R., Torri, C., Fabbri, D., and Cozzani, V. (2016). Waste to energy volarization of poultry litter by slow pyrolysis. Renewable Energy, 90, 458 - 468.

7. Burhenne, L., Messmer, J., Aicher, T., and Laborie, M. (2013). The effect of the biomass components lignin, cellulose and hemicellulose on TGA and fixed bed pyrolysis. Journal of Analytical and Applied Pyrolysis, 101, 177-184.

8. DeGroot, W.F. and Shafizadeh, F. (1984). The influence of exchangeable cations on the carbonization of biomass. Journal of Analytical and Applied Pyrolysis, 6, 217- 232.

9. Di Blasi, C. and Branca, C. (2001). Kinetics of primary product formation from wood pyrolysis. Industrial Engineering Chemistry Research, 40, 5547-5556.

10. Di Blasi, C., Branca, C., Santoro, A. and Gonzalec Hernandez, E. (2001). Pyrolytic behaviour and products of some wood varieties. Combustion and Flame, 124, 165-177.

11. Di Blasi, C., Signorelli, G., Di Russo,C. and Rea, D. (1999). Product distribution from pyrolysis of wood and agricultural residues. Industrial \& Engineering Chemistry Research, 38, 2216 - 2224.

12. Ezeonu, C.S., Otitoju, O., Onwurah, I.N.E., Ejikeme, C.M., Ugbogu, O.C., and Anike, E.N. (2014). Enhanced availability of biofuel and biomass components in Aspergillus niger and Aspergillus fumigatus treated rice husk. European Scientific Journal, 10(18), 96-117.

13. Hirosaka, K., Yuvamitra, K., Ishikawa, A., and Hasegawa T. (2008). Efficiencies of power plants using hydrothermal oxidation. Journal of Thermal Science and Engineering, 16(1), 1-9.

14. Horne, P.A. and Williams, P.T. (1996). Influence of temperature on the products from the flash pyrolysis of biomass. Fuel 75, 1051-1059.

15. Jahirul, M. I., Rasul, M. G., Chowdhury, A. A., and Ashwath, N. (2012). Biofuels production through biomass pyrolysis- A technological review. Energies, 5(12), 4952-5001.

16. Kim S., Agblevor, F.A., and Lim, J. (2009). Fast pyrolysis of chicken litter and turkey litter in a fluidized bed reactor. Journal of Industrial and Engineering Chemistry, 15, 247-252.

17. Lu, H., Ip, E., Scott, J., Foster, P., Vickers, M. and Baxter, L.L. (2010). Effects of particle shape and size on devolatilization of biomass particle. Fuel, 89, 1156-1168. 
18. Mante, O.D. and Agblevor F.A. (2010). Influence of pine wood shavings on the pyrolysis of poultry litter. Waste Management, 30, $2537-2547$.

19. Okekunle, P.O., Adunola, V.L., Whanvoh, E.S., Afolabi, A.P., and Idiok, E.P. (2015). Experimental investigation of the effect of sample shape on biomass pyrolysis characteristics in a fixed bed reactor. Journal of Natural Sciences Research, 5(10), 120 - 126.

20. Okekunle, P.O., Itabiyi, O.E., Adetola, S.O., Alayande, I.O., Ogundiran, H.O., and Odeh, K.G. (2016). Biofuel production by pyrolysis of cassava peel in a fixed bed reactor. International Journal of Energy for a Clean Environment, 17(1), 57- 65.

21. Okekunle, P.O., Pattanotai, T., Watanabe, H. and Okazaki, K. (2011). Numerical and experimental investigation of intra-particle heat transfer and tar decomposition during pyrolysis of wood biomass. Journal of Thermal Science and Technology, 6 (3), 360-375.

22. Olumayowa, O. and Abiodun, O.O. (2011). Profit efficiency and waste management in poultry farmimg: The case of Egba division, Ogun state, Nigeria. International Journal of Poultry Science, 10(2), 137142.

23. Parveen, M., Islam, M.R., and Haniu H. (2011). Thermal decomposition behavior study of two agricultural solid wastes for production of bio-fuels by pyrolysis technology. Journal of Thermal Science and Technology, 6(1), 132-139.

24. Piskorz, J., Majerski, P., Radlein, D., Scott, D.S., and Bridgwater, A.V. (1998). Fast pyrolysis of sweet sorghum and sweet sorghum bagasse. Journal of Analytical and Applied Pyrolysis, 46, 15-29.

25. Scott, D.S. and Piskorz, J. (1982). The flash pyrolysis of aspen-poplar wood. Canadian Journal of Chemical Engineering, 60, 666-674. In modeling chemical and physical processes of wood and biomass pyrolysis, Progress in Energy and Combustion Science, 34 (2008), 4790.

26. Scotts, D.S., Piskorz, J., Bergougnou, M.A., Graham, R., and Overend, R.P. (1988). The role of temperature in the fast pyrolysis of cellulose and wood. Industrial Chemistry Research, 27, 8-15.

27. Yang, H., Yan, R., Chen, H., Lee, D.H., Liang, D.T., and Zheng, C. (2006). Pyrolysis of palm oil wastes for enhanced production of hydrogen rich gases. Fuel Processing Technology, 87, 935-942. 